\title{
PENINGKATAN PEMAHAMAN KONSEP SIFAT-SIFAT BANGUN \\ RUANG SEDERHANA MELALUI MEDIA KOTAK/KUBUS \\ PADA SISWA KELAS IV SDN NGAMPELREJO \\ KECAMATAN JOMBANG KABUPATEN JEMBER \\ SEMESTER GENAP TAHUN 2018/2019
}

AGUS PAMBUDI

SDN NGAMPELREJO 02

\begin{abstract}
Abstrak, Peningkatan pemahaman konsep sifat-sifat bangun ruang sederhana kotak / kubus pada siswa kelas IV SDN Ngampelrejo 02 Kab.Jember.Sebagai seorang guu yang ingin meningkatkan pemahaman konsep pada muridnya berusaha semaksimal mungkin dengan berbagai cara yang baik sudah dilakukan,pengaruh lingkungan dan lingkungan sekolah juga ikut mendukung dalam mensukseskan usaha guru
\end{abstract}

Kata kunci: Bangun ruang sederhana, kotak kubus

\section{PENDAHULUAN}

\section{Latar Belakang Masalah}

Proses belajar mengajar yang

tidak lepas dari bagaiamana seorang guru memberikan media pengajaran, metode pengajaran, dan keterampilan mengajar. Metode mengajar merupakan cara-cara yang ditempuh guru menciptakan situasi pengajaran yang benar-benar menyenangkan dan mendukung bagi kelancaran proses belajar dan tercapainya prestasi belajar anak yang memuaskan (Sunaryo, 1995).

Dalam hal ini penulis perlu mengadakan penelitian tindakan kelas di SDN Ngampelrejo 02 khususnya Kelas 4 dengan beberapa alasan sebagai berikut:

a. Di Kelas 4 untuk mata pelajaran Matematika dengan materi Memahami sifat bangun ruang 
sederhana dan hubungan antar bangun datar, dari 33 siswa yang mencapai ketuntasan belajar hanya $40 \%$ karena siswa kurang paham tentang sifat-sifat bangun ruang jika tidak menggunakan media kongkrit.

b. Guru mengajarkan materi tentang sifat-sifat bangun ruang dengan menggunakan Media seadanya ( gambar-gambar bangun ruang Kubus dan Balok yang ada di dalam buku pelajaran ).

Data yang penulis peroleh di atas perlu adanya identifikasi masalah yaitu:

1. Data a sampai dengan b merupakan masalah pembelajaran yang dapat diperbaiki oleh guru

Menindaklanjuti dua masalah di atas (a dan b), perlu dianalisis penyebab masalah yang terjadi yaitu:
- Apersepsi yang dilakukan guru kurang terarah

- Alokasi waktu kurang dari jatah waktu yang ditentukan

- Penggunaan metode mengajar dan keterampilan dalam mengajar kurang bervariasi

- Penggunaan Media masih menggunakan contoh gambar kubus dan balok dari buku paket siswa dan belum menemukan yang tepat untuk materi yang diajarkan

Dari analisis yang penulis peroleh di atas maka data a merupakan akar masalah yang perlu diteliti. Untuk itu penulis memberikan beberapa pemecahan sebagai berikut:

- Guru perlu memaksimalkan waktu apersepsi untuk dapat membuka pelajaran 


- Guru harus membuat
Rencana Pembelajaran untuk
yang matang dengan
alokasi waktu yang tepat
- Guru perlu memberikan
pengajaran dengan
menggunakan media
pengajaran, variasi metode
pengajaran dan
keterampilan mengajar

2. Rumusan Masalah

Dari hasil analisis yang penulis lakukan, adapun masalah dirumuskan sebagai berikut:

$\begin{array}{lr}\text { Apakah } & \text { dengan } \\ \text { menggunakan } & \text { Media } \\ \text { Kotak/Kubus } & \text { dapat } \\ \text { meningkatkan } \quad \text { pemahaman } & \\ \text { konsep sifat-sifat bangun } & \text { siswa } \\ \text { ruang sederhana Pada } & \text { Negeri } \\ \text { Kelas } 4 \quad \text { SD } \quad \text { Tahun } \\ \text { Ngampelrejo } \quad 02\end{array}$

3. Tujuan Penelitian
Penelitian ini bertujuan

1. Meningkatkan

pemahaman sifatsifat bangun ruang sederhana melalui penggunaan media kotak/kubus.

2. Mendeskripsikan penggunaan media pengajaran berupa Kotak/Kubus untuk mengenal konsep bangun ruang dalam pembelajaran

3. Mendeskrisikan pengaruh/dampak penggunaan media pengajaran berupa Kotak/Kubus untuk mengenal konsep bangun ruang dalam pembelajaran.

\section{Manfaat Penelitian}


(1) Manfaat bagi

peneliti

- Menambah wawasan untuk lebih mengoptimalkan

proses pembelajaran

yang terarah

- Dapat meningkatkan kinerja guru yang maksimal sehingga menjadi guru yang professional.

(2) Bagi Guru

\section{- Guru} dapat memperbaiki cara mengajar dengan memenfaatkan media pengajaran sederhana berupa Kotak/Kubus

(3) Bagi Siswa

- Siswa lebih tertarik pada materi pelajaran yang disampaikan guru
- Presentasi

keberhasilan belajar siswa meningkat

(4) Manfaat bagi Sekolah

- Meningkatkan

Sumber Daya guru yang ada supaya menjadi guru yang profesional

\section{METODE PENELITIAN}

\section{Pendekatan/Jenis}

Media pengajaran atau pendidikan menurut Gagne dan Reiser (1983:3) adalah sebagai alatalat fisik di mana pesan-pesan instruksional dikomunikasikan. Jadi seorang instruktur, buku cetak, pertunjukan film atau tape recorder dan lain-lain peralatan fisik yang mengkomunikasikan pesan instruksional dianggap sebagai media.

Yang dimaksud dengan media pengajaran adalah segala alat 
pengajaran yang digunakan guru sebagai perantara untuk menyampaikan bahan-bahan instruksional dalam proses belajar mengajar sehingga memudahkan pencapaian tujuan pengajaran tersebut.

\section{Rancangan Penelitian}

Secara khusus media pengajaran digunakan dengan tujuan sebagai berikut:

\section{Memberikan}

kemudahan kepada peserta didik untuk lebih memahami konsep, prinsip, sikap dan keterampilan tertentu dengan menggunakan media yang paling tepat

2. Memberikan

pengalaman belajar yang berbeda dan bervariasi sehingga lebih merangsang minat peserta didik untuk belajar
3. Menciptakan situasi belajar yang tidak dapat dilupakan peserta didik

\section{Subyek Penelitian}

Penentuan tempat penelitian ini ditentukan oleh peneliti di Kelas 4 SDN Ngampelrejo 02 dengan pertimbangan, tingkat pemahaman tentang konsep sifat-sifat bangun ruang masih rendah terbukti dengan hasil evaluasi akhir 50\% dibawah rata-rata.

Tempat penelitian ini ditetapkan di SD Negeri Ngampelrejo 02 yang beralamat di Desa Ngampelrejo Kecamatan Jombang Kabupaten Jember, mulai tanggal 20 April 2019 s/d 25 April 2019.

\footnotetext{
Penentuan subyek penelitian menggunakan metode purposive sampling didasarkan atas kondisi objektif di mana sebagian besar motivasi belajar siswa rendah pada
} 
mata pelajaran Matematika. Subjek

penelitian adalah seluruh siswa Kelas

4 yang berjumlah 33 orang.

\section{Metode Pengumpulan Data}

Dalam suatu penelitian di samping menggunakan metode yang tepat juga perlu memilih teknik dan alat pengumpulan data yang tepat memungkinkan diperolehnya data yang obyektif. Adapun pengumpulan data yang digunakan dalam penelitian ini adalah sebagai berikut:

1) Metode Observasi

Menurut DR. Nana Sudjana dan DR. Ibrahim : “Observasi sebagai alat pengumpul data banyak digunakan untuk mengukur tingkah laku individu ataupun proses terjadinya suatu kegiatan yang dapat diamati baik dalam situasi yang sebenarnya maupun dalam situasi buatan" (2001:109)

\section{Instrumen Penilaian}

Indikator keberhasilan dalam penelitian ini adalah apabila guru dapat menerapkan metode pembelajaran dengan Media Kotak/Kubus, Desain Solusi, Formulasi terhadap hasil belajar matematika siswa Kelas 4 SD Negeri Ngampelrejo 02 semester II tahun pembelajaran 2018/2019, khususnya siswa aktif dalam pembelajaran dengan Media Kotak/Kubus terhadap hasil belajar matematika kompetensi dasar "Menentukan sifat-sifat bangun ruang sederhana “ Kelas 4 yaitu siswa mampu menemukan, mengumpulkan, menganalisis, dan mengintepretasi sifat-sifat bangun ruang menggunakan Media Kotak/Kubus sehingga mereka menemukan, menentukan dan membaca sifat-sifat bangun ruang.

\section{Subyek Penelitian}


Tempat dan Waktu

Pelaksanaan

Pelaksanaan

perbaikan

pembelajaran dilaksanakan di Kelas

$4 \quad$ SD Negeri Ngampelrejo 02

Kecamatan Jombang Kabupaten

Jember. Dilaksanakan pada tanggal

21 April 22 dan 23 April 2019

dengan ditemani teman sejawat yang

mengamati jalannya Penelitian

Tindakan Kelas ini.

\section{Tehnik Analisis Data}

Data yang diperoleh melalui metode pengumpulan data masih mentah. Untuk dapatnya diambil suatu kesimpulan akhir, maka diperlukan analisa data yang tepat sebagai proses untuk mengambil kesimpulan tersebut.

Data yang akan dianalisa dalam penelitian ini adalah:

1) Kegitan siswa selama proses kegiatan belajar mengajar berlangsung yang semuanya diperoleh dari observasi yakni meliputi aspek afektif dan psikomotorik;

2) Hasil tugas dan ulangan harian siswa (aspek kognitif)

Untuk mengukur ketuntasan hasil belajar dalam hal ini adalah aspek kognitif, afektif dan psikomotorik menggunakan standar ketuntasan yaitu ketuntasan belajar individu dinyatakan tuntas apabila tingkat presentase ketuntasan minimal mencapai $65 \%$, sedangkan untuk tingkat klasikal minimal mencapai 85\% (Depdikbud:1994).

Adapun untuk mengetahui ketuntasan hasil belajar adalah dengan menggunakan rumus persentase ketuntasan hasil belajar, yaitu:

a) Ketuntasan secara individu Rumus Presentase Ketuntasan

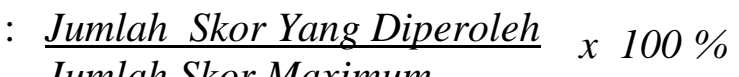
Jumlah Skor Maximum

b) Ketuntasan secara Klasikal : 
Rumus Presentase Ketuntasan efektifitasnya, maka $x \quad 100 \%$

: Jumlah Siswa Yang Tuntas $\quad x 100 \%$ ılajaran dengan Media jam Jumlah Seluruh Siswa

mendapat prestasi $\mathrm{x}+(\mathrm{ER}+\mathrm{y})$ jadi

Untuk mengetahui efektivitas jika nilai ER lebih besar dari $0 \%$

hasil belajar matematika maka maka dapat dikatakan bahwa digunakan rumus sebagai berikut : pembelajaran di kelas dengan Media

$\mathrm{ER}=\frac{M x-M y}{M y} \times 100$ Kotak/Kubus lebih efektif dibanding dengan pembelajaran sebelumnya Keterangan:

ER : Tingkat keefektifan relative

Mx : Nilai rata-rata kelas setelah dilakukan tindakan

My : Nilai rata-rata kelas sebelum dilakukan tindakan

Hasil penghitungan tingkat keefektifan relative (ER) dapat disimpulkan apakah pembelajaran dengan Media jam lebih efektif atau tidak (dalam \%) dibandingkan dengan pengajaran sebelumnya dimana $\mathrm{Mx}$ adalah nilai rata-rata kelas setelah dilakukan tindakan dan My adalah nilai sebelum dilakukan tindakan dan ER adalah nilai (Masyud, 2000:61).

\section{HASIL PENELITIAN}

\section{Hasil Penelitian}

Setelah melakukan perbaikan pembelajaran setiap siswa diberi tes formatif yaitu siklus I dan tes formatif siklus II dengan tujuan untuk mengetahui tingkat keberhasilan siswa dalam proses perbaikan pembelajaran. Adapun data penilaian dalam proses perbaikan pembelajaran persiklus adalah sebagai berikut :

\section{Pembahasan}

Tabel Sebelum Perbaikan Mata Pelajaran Matematika ( Prasiklus) 


\begin{tabular}{|c|c|c|c|c|c|}
\hline No & Nama Siswa & Skor & Tuntas & $\begin{array}{c}\text { Tidak } \\
\text { Tuntas }\end{array}$ & keterangan \\
\hline 1 & M Salim & 75 & $\sqrt{ }$ & & \\
\hline 2 & A Baidowi & 75 & $\sqrt{ }$ & & \\
\hline 3 & A Syaifudin & 65 & $\sqrt{ }$ & & \\
\hline 4 & Abdul Rohim & 60 & & $\sqrt{ }$ & \\
\hline 5 & Ahmad Rosi & 80 & $\sqrt{ }$ & & \\
\hline 6 & M Riski Darmawan & 70 & $\sqrt{ }$ & & \\
\hline 7 & Ibnu Supriyadi & 60 & & $\sqrt{ }$ & \\
\hline 8 & Dewi Alya Damayanti & 75 & $\sqrt{ }$ & & \\
\hline 9 & Rani Fitri Diansari & 60 & & $\sqrt{ }$ & \\
\hline 10 & Sti Faizatul Aliyah & 40 & & $\sqrt{ }$ & \\
\hline 11 & Ike Wahyuning Tyas & 60 & & $\sqrt{ }$ & \\
\hline 12 & M shohibullah & 60 & & $\sqrt{ }$ & \\
\hline 13 & Camelia fitria & 50 & & $\sqrt{ }$ & \\
\hline 14 & Heriyanto & 60 & & $\sqrt{ }$ & \\
\hline 15 & Cindy widya Ri & 50 & & $\sqrt{ }$ & \\
\hline 16 & Devi Irviana & 80 & $\sqrt{ }$ & & \\
\hline 17 & Diva Ramadhani & 65 & $\sqrt{ }$ & & \\
\hline 18 & Prayogi & 60 & & $\sqrt{ }$ & \\
\hline 19 & Aryo rendika & 75 & $\sqrt{ }$ & & \\
\hline 20 & Nawardi & 70 & $\sqrt{ }$ & & \\
\hline 21 & Labib Husein & 60 & & $\sqrt{ }$ & \\
\hline 22 & Fuadi & 50 & & $\sqrt{ }$ & \\
\hline 23 & Dwi Kurniawati & 40 & & $\sqrt{ }$ & \\
\hline 24 & Evi Wahyuni & 80 & $\sqrt{ }$ & & \\
\hline 25 & Feby Nurul & 75 & $\sqrt{ }$ & & \\
\hline 26 & Halimatus Sakdiyah & 65 & $\sqrt{ }$ & & \\
\hline 27 & Yuni Manda & 60 & & $\sqrt{ }$ & \\
\hline 28 & Wiwin Riski & 80 & $\sqrt{ }$ & & \\
\hline 29 & Siska Noviyanti & 60 & & $\sqrt{ }$ & \\
\hline 30 & Helmi andiyan & 60 & & $\sqrt{ }$ & \\
\hline 31 & Vania & 40 & & $\sqrt{ }$ & \\
\hline
\end{tabular}




\begin{tabular}{|l|l|c|c|c|c|}
\hline 32 & Rizquna Damayanti & 50 & & $\sqrt{ }$ & \\
33 & Nurmayanti & 60 & & $\sqrt{ }$ & \\
\hline & Jumlah Skor & 1970 & & & \\
\hline & Jumlah Skor Maksimum & 2970 & & & \\
\hline & \% Skor Tercapai & $42 \%$ & & & \\
\hline
\end{tabular}

Keterangan :

Jumlah siswa tuntas $\quad: 14$ siswa

Jumlah siswa tidak tuntas : 19 siswa

Klasikal : Belum Tuntas

Tabel Daftar Skala Nilai Matematika Kelas 4 Prasiklus

\begin{tabular}{|c|c|c|c|c|c|}
\hline No & Skala Nilai & Kriteria & $\begin{array}{c}\text { Jumlah } \\
\text { Siswa }\end{array}$ & $\begin{array}{c}\text { Jumlah Siswa } \\
\text { Keseluruhan }\end{array}$ & $\begin{array}{c}\text { Jumlah } \\
\%\end{array}$ \\
\hline 1 & $0-50$ & Kurang & 7 & 33 & $21 \%$ \\
\hline 2 & $51-60$ & Cukup & 12 & & $36 \%$ \\
\hline 3 & $61-70$ & Cukup & 5 & & $15 \%$ \\
\hline 4 & $71-80$ & Baik & 9 & & $27 \%$ \\
\hline 5 & $81-90$ & Baik & - & & $0 \%$ \\
\hline 6 & $91-100$ & Baik sekali & - & & $0 \%$ \\
\hline & & & & & \\
\hline
\end{tabular}

Kesimpulan :

- $\quad$ Siswa yang mendapat nilai kurang 7

- Siswa yang mendapat nilai cukup 17 siswa

- Siswa yang mendapat nilai baik 9 siswa

- $\quad$ Siswa yang mendapat nilai baik sekali 0 .

\section{Pembahasan}


Tabel Nilai Evaluasi Setelah Perbaikan Siklus II

\begin{tabular}{|c|c|c|c|c|c|}
\hline No & Nama Siswa & Skor & Tuntas & $\begin{array}{l}\text { Tidak } \\
\text { Tuntas }\end{array}$ & keterangan \\
\hline 1 & M Salim & 80 & $\sqrt{ }$ & & \\
\hline 2 & A Baidowi & 80 & $\sqrt{ }$ & & \\
\hline 3 & A Syaifudin & 75 & $\sqrt{ }$ & & \\
\hline 4 & Abdul Rohim & 70 & $\sqrt{ }$ & & \\
\hline 5 & Ahmad Rosi & 90 & $\sqrt{ }$ & & \\
\hline 6 & M Riski Darmawan & 80 & $\sqrt{ }$ & & \\
\hline 7 & Ibnu Supriyadi & 65 & $\sqrt{ }$ & & \\
\hline 8 & Dewi Alya Damayanti & 90 & $\sqrt{ }$ & & \\
\hline 9 & Rani Fitri Diansari & 65 & $\sqrt{ }$ & & \\
\hline 10 & Sti Faizatul Aliyah & 65 & $\sqrt{ }$ & & \\
\hline 11 & Ike Wahyuning Tyas & 70 & $\sqrt{ }$ & & \\
\hline 12 & M shohibullah & 70 & $\sqrt{ }$ & & \\
\hline 13 & Camelia fitria & 65 & $\sqrt{ }$ & & \\
\hline 14 & Heriyanto & 65 & $\sqrt{ }$ & & \\
\hline 15 & Cindy widya Ri & 65 & $\sqrt{ }$ & & \\
\hline 16 & Devi Irviana & 90 & $\sqrt{ }$ & & \\
\hline 17 & Diva Ramadhani & 75 & $\sqrt{ }$ & & \\
\hline 18 & Prayogi & 70 & $\sqrt{ }$ & & \\
\hline 19 & Aryo rendika & 85 & $\sqrt{ }$ & & \\
\hline 20 & Nawardi & 80 & $\sqrt{ }$ & & \\
\hline 21 & Labib Husein & 70 & $\sqrt{ }$ & & \\
\hline 22 & Fuadi & 65 & $\sqrt{ }$ & & \\
\hline 23 & Dwi Kurniawati & 65 & $\sqrt{ }$ & & \\
\hline 24 & Evi Wahyuni & 90 & $\sqrt{ }$ & & \\
\hline 25 & Feby Nurul & 85 & $\sqrt{ }$ & & \\
\hline 26 & Halimatus Sakdiyah & 75 & $\sqrt{ }$ & & \\
\hline 27 & Yuni Manda & 70 & $\sqrt{ }$ & & \\
\hline 28 & Wiwin Riski & 90 & $\sqrt{ }$ & & \\
\hline 29 & Siska Noviyanti & 70 & $\sqrt{ }$ & & \\
\hline
\end{tabular}




\begin{tabular}{|c|l|c|c|l|l|}
\hline 30 & Helmi andiyan & 70 & $\sqrt{ }$ & & \\
31 & Vania & 65 & $\sqrt{ }$ & & \\
32 & Rizquna Damayanti & 65 & $\sqrt{ }$ & & \\
33 & Nurmayanti & 70 & $\sqrt{ }$ & & \\
\hline & Jumlah Skor & 2440 & & & \\
\hline & Jumlah Skor Maksimum & 2970 & & & \\
\hline & \% Skor Tercapai & $100 \%$ & & & \\
\hline
\end{tabular}

Keterangan :

Jumlah siswa tuntas $\quad: 33$ siswa

Jumlah siswa tidak tuntas : 0 siswa

Klasikal : Tuntas

Tabel Daftar Skala Nilai Matematika Kelas 4 Siklus II

\begin{tabular}{|c|c|c|c|c|c|}
\hline No & Skala Nilai & Kriteria & $\begin{array}{c}\text { Jumlah } \\
\text { Siswa }\end{array}$ & $\begin{array}{c}\text { Jumlah Siswa } \\
\text { Keseluruhan }\end{array}$ & $\begin{array}{c}\text { Jumlah } \\
\%\end{array}$ \\
\hline 1 & $0-50$ & Kurang & - & 33 & $0 \%$ \\
\hline 2 & $51-60$ & Cukup & - & & $0 \%$ \\
\hline 3 & $61-70$ & Cukup & 19 & & $58 \%$ \\
\hline 4 & $71-80$ & Baik & 7 & & $21 \%$ \\
\hline 5 & $81-90$ & Baik & 7 & & $21 \%$ \\
\hline 6 & $91-100$ & Baik sekali & - & & $0 \%$ \\
\hline & & & & & \\
\hline
\end{tabular}

Kesimpulan :

- $\quad$ Siswa yang mendapat nilai kurang 0

- Siswa yang mendapat nilai cukup turun dari 25 menjadi 19 siswa

- Siswa yang mendapat nilai baik naik dari 5 menjadi 14 siswa

- Siswa yang mendapat nilai baik sekali 0 .

Tabel Rekapitulasi Hasil Tes Siswa Pada Mata Pelajaran Matematika

\begin{tabular}{|c|c|c|c|c|}
\hline NO & URAIAN & HASIL & HASIL & HASIL \\
& PRASIKLUS & SIKLUS I & SIKLUS II \\
\hline
\end{tabular}




\begin{tabular}{|c|l|c|c|c|}
\hline 1 & Nilai rata-rata hasil formatif & 64 & 69 & 76 \\
\hline 2 & Jumlah siswa yang tuntas & 14 & 22 & 33 \\
\hline 3 & Prosentase ketuntasan & $42 \%$ & $67 \%$ & $100 \%$ \\
\hline
\end{tabular}

Berdasarkan hasil diskusi teman sejawat perbaikan pembelajaran yang dilaksanakan sudah menunjukkan peningkatan. Hal ini ditujukan dengan nilai rata-rata persiklusnya terus mengalami perbaikan. Rangkuman dari ketiga siklus adalah sebagai berikut :

Tabel Rangkuman Hasil Prasiklus, Siklus I, Siklus II Berdasarkan Kriteria Nilai.

\begin{tabular}{|c|c|c|c|c|c|}
\hline No & Skala Nilai & Kriteria & $\begin{array}{c}\text { Prasiklus } \\
\%\end{array}$ & $\begin{array}{c}\text { Siklus I } \\
\%\end{array}$ & $\begin{array}{c}\text { Siklus II } \\
\%\end{array}$ \\
\hline 1 & $0-50$ & Kurang & $21 \%$ & $9 \%$ & $0 \%$ \\
\hline 2 & $51-60$ & Cukup & $36 \%$ & $24 \%$ & $0 \%$ \\
\hline 3 & $61-70$ & Cukup & $15 \%$ & $52 \%$ & $58 \%$ \\
\hline 4 & $71-80$ & Baik & $27 \%$ & $15 \%$ & $21 \%$ \\
\hline 5 & $81-90$ & Baik & $0 \%$ & $0 \%$ & $21 \%$ \\
\hline 6 & $91-100$ & Baik sekali & $0 \%$ & $0 \%$ & $0 \%$ \\
\hline
\end{tabular}

Berdasarkan tabel diatas, hasil nilai

Matematika Kelas 4 mengalami

peningkatan dapat dijelaskan sebagai

berikut :

- Kriteria nilai kurang

Prasiklus $21 \%$, siklus I 9

$\%$ dan siklus II $0 \%$

- Kriteria nilai cukup

Prasiklus $51 \%$, siklus I

$76 \%$, dan siklus II $58 \%$

- Kriteria nilai baik

Prasiklus $27 \%$, siklus I

$15 \%$, dan siklus II $42 \%$

- Kriteria nilai baik sekali 0

$\%$

\section{E. PEMBAHASAN}


Berdasarkan hasil tes prestasi siswa, setiap siklus menunjukkan bahwa dengan perbaikan pembelajaran siswa banyak diberi kesempatan untuk berdiskusi bersama kelompoknya dan melakukan percobaan serta mengamati hasilnya.

Berdasarkan hasil observasi dengan teman sejawat diperoleh keaktifan siswa dalam proses pembelajaran menggunakan metode eksperimen, alat peraga yang sesuai, mencoba dan memperagakan sendiri. Keaktifan guru muncul diantaranya membimbing dan melatih siswa menggunakan alat peraga, mengamati kerja siswa, memberi tugas dan evaluasi.

\section{F.PENUTUP}

\section{Kesimpulan}

Hasil perbaikan pembelajaran pada pelajaran matematika yang telah dilaksanakan di SD Negeri
Wringinagung 02 Kecamatan Ajung Kabupaten Jember pada siswa Kelas 4 semester II tahun pelajaran 2018/2019 dapat ditarik kesimpulan sebagai berikut :

a. Penggunaan media kotak/kubus memotivasi siswa untuk mepelajari sifat-sifat bangun ruang.

b. Penggunaan Media yang optimal dapat meningkatkan penguasaan sifat-sifat bangun ruang.

c. Pengajaran dengan menggunakan media pengajaran, variasi dari metode dan keterampilan mengajar, serta dapat memudahkan guru dalam menyampaikan materi pembelajaran kepada siswa.

\section{Saran}

Berdasarkan pengalaman melaksanakan perbaikan pembelajaran melalui penelitian tindakan kelas perlu adanya : 
- Rencana

pembelajaran yang disusun

secara matang.

- Media kotak/kubus untuk

meningkatkan pemahaman siswa

terhadap materi sifat-sifat bangun

ruang.

- Metode mengajar yang bervariasi sehingga mampu menarik perhatian siswa dan tidak membosankan.

\section{G. DAFTAR PUSTAKA}

Andayani, dkk (2007). Pemantapan Kemampuan Profesional

(Panduan). Jakarta:Universitas Terbuka.

Derek Rowntrie (1982:168). Hand

Out Media Pengajaran. Unej.
Dinje Borman Rumumpuk (1988:6).

Hand Out Media Pengajaran. Unej.

Gagne dan Reiser (1983:3). Hand Out Media Pengajaran. Unej.

Janice Vancleave's. 2003. Matematika Untuk Anak. PT. Intan Sejati: Bandung.

Nana Sudjana dan Ibrahim. (2001). Penelitian dan Penilaian Pendidikan. Sinar Baru:Algesindo.

Rachmat, dkk. Belajar Matematika. Bandung: PT. Sarana Pancakarya Nusa:Surabaya.

Sri Anitah Wiryawan dan Noorhadi Th. (1994). Hand Out Media Pengajaran. Unej.

Sunaryo. (1995). Hand Out Media Pengajaran. Unej.

Supardjo. 2004. Gemar Berhitung. Solo: PT. Tiga Serangkai Pustaka Mandiri : Solo. 